\title{
THE NATIONAL MUSEUM OF FINE ARTS OF SANTIAGO AND ITS PUBLICATIONS (1922-2009) ${ }^{1}$
}

\author{
El Museo Nacional de Bellas Artes de Santiago (Chile) a través de sus publicaciones: \\ 1922-2009
}

\author{
Albert Ferrer Orts* \\ Alberto Madrid Letelier**
}

This article forms part of the project "Ausencia de una política o política de la ausencia.
Institucionalidad y desarrollo de las artes visuales en Chile 1849-1973" Fondecyt No 1140370,
whose co-researcher is one of the authors of this publication.
This paper was initially sent for review in Spanish, and it has been translated into English
with the support of the Project FP150008, "Aumento y mejora del índice de impacto y de la
internacionalización de la revista Universum por medio de la publicación de un mayor número
de artículos en inglés." Fund for publication of Scientific Journals 2015, Scientific Information
Program, Scientific and Technological Research National Commission (Conicyt), Chile.

Este artículo fue enviado a revisión inicialmente en español y ha sido traducido al inglés gracias al Proyecto FP150008, "Aumento y mejora del índice de impacto y de la internacionalización de la revista Universum por medio de la publicación de un mayor número de artículos en inglés". Fondo de Publicación de Revistas Científicas 2015, Programa de Información Científica, Comisión Nacional de Investigación Científica y Tecnológica (Conicyt), Chile.

* Faculty of Art, Universidad de Playa Ancha de Ciencias de la Educación. Valparaíso, Chile. Email: albert.ferrer-orts@uv.es

** Faculty of Art, Universidad de Playa Ancha de Ciencias de la Educación. Valparaíso, Chile. Email: amadridlet@gmail.com

Article received April 28, 2015. Accepted September 4, 2015. 


\begin{abstract}
In this article we will review publications from the National Museum of Fine Arts in Santiago between 1922 and 2009 in the Chilean cultural context. Not included in this study are the catalogs of funding of temporary exhibitions that have generated since its founding in 1880 as the National Museum of Painting. It is a rather small publication in one of the first American museums of its kind.
\end{abstract}

Keywords: Museo Nacional de Bellas Artes, Santiago, Chile, bibliography, 1922-2009.

\title{
RESUMEN
}

En este artículo hacemos un repaso a las publicaciones que el Museo Nacional de Bellas Artes en Santiago ha venido realizando entre 1922 y 2009 sobre su idiosincrasia en el contexto cultural chileno. No se incluyen, por tanto, en este estudio los catálogos de las exposiciones temporales de sus fondos que ha ido generando desde su fundación en 1880 como Museo Nacional de Pintura. Una producción editorial más bien escasa en uno de los primeros museos de América en su género dada su importancia cultural.

Palabras clave: Museo Nacional de Bellas Artes, Santiago, Chile, bibliografía, 1922-2009.

One of the problems that we still encounter today, in what is called generically the "arts system" in Chile, is the precarious nature of references made to primary sources in research documentation. Notable shortcomings and citation gaps result in a degree of apprehension on the part of potential researchers. A fatal confluence of factors, though attempts have been made to reverse them, are mediating the research tasks as doubts repeatedly surface related to the accuracy of data and chronology of events. These factors raise concerns regarding the histiographical discourse and a lack of a sound empirical basis. Although this is not a new question, it will here be framed in a wider panorama that addresses the character of the Chilean identity.

Since the first generation of students took an interest in defining the characteristics of the new nation and its historical, cultural and artistic discourse, it was from the viewpoint of a select cast of political and economic elite from Santiago that these came to be represented in the literature. Although this effort has constituted a great benefit to the Chilean people, it has at the same time created a way of conducting and presenting research that is overly subjective. In this context we must not overlook the backgrounds, family origins, and both the economic and political class interests of the authors who have sought to understand, and even claim as theirs, the culture which they work to define. 
This phenomenon is not exclusive to contemporary Chile as it was also common in Europe, a continent to which America has always looked with a sideways glance. The difference lies perhaps in its perpetuation over time, fueled by the scientific shortcomings of Chile's universities that extended well into the 1970 's. What deepened the debate, from an objective and critical standpoint, was the fact that this trend was growing in almost every aspect while polarizing those with a traditional, classical view and those advocating an openness to change. There was an expanding gap between the representatives of the aristocracy and the republican meritocracy as demonstrated clearly, for example, in the contrast between the papers of Blanco and Lira in the last quarter of the nineteenth century ${ }^{2}$.

When comparing those who have conformed to the political apex and those who have made up the artistic and literary cultural institutions in Chile since the mid-1800s, an unresolved dichotomy can be identified that runs well into the twentieth century. Since the times of Barros Arana, Benjamin Vicuña and Pedro Lira, to those of Rafael Errázuriz, Alberto Mackenna and Álvarez Urquieta, family origin has systematically reproduced the state administration as with the unequal counterbalance by the likes of José Miguel Blanco, Juan Francisco González, Álvarez Sotomayor and the Generation of '13. The repetition of this imbalanced model has had a significant impact on both the historical and artistic discourse in Chile.

This duality eventually resulted in the creation of the Museo Nacional de Pintura (National Painting Museum) first located in the Congress in Santiago, later relocated to the Partenón de Quinta Normal, and finally to Parque Forestal along the banks of the Mapocho river where it remained along with its internal organization, management and interests ${ }^{3}$. Here the collections that have been gathered since its inception can be found, stockpiles from other state institutions, generous inheritances such as those from Eusebio Lillo, certain works of the Exhibition of 1910, and the Collection of Álvarez Urquieta among others.

As far as we know, these collections remained pending an inventory summary and catalog registration as would be the case in any similar museum looking to ensure the integrity of its assets. The first such record was compiled by Cousiño between 1880 and 1922 and however late, was released to the public revealing the museum's holdings. This priceless work, as we shall see, has neither been repeated nor improved though has since become readily available to the general public on the Internet.

\footnotetext{
${ }^{2}$ Herrera (2014): 61-70.

${ }^{3}$ Berríos et al. (2009): 348 ss.
} 


\section{THE NATIONAL MUSEUM OF FINE ARTS, A CHILEAN ARTISTIC ICON}

With the creation of the National Painting Museum by the National Congress in Santiago on September 18, 1880, the capital of Chile became the second city in the Americas to possess a museum of fine arts after the Metropolitan Museum of Art in New York (1866) ${ }^{4}$. It was a milestone not much taken into account by the historiography of Chilean art whose establishment was owed, fundamentally, to the will of the sculptor José Miguel Blanco $(1839-1897)^{5}$, the painter Giovanni Mochi (1831-1892), the offices of the then Minister of Justice and Public Instruction Manuel García de la Huerta, and to the President of the Nation Aníbal Pinto.

Unprecedently, 140 works of art previously scattered throughout several public offices were brought together, donated in part by the military which had its first independent headquarters in the Partenón de la Quinta Normal de Agricultura. The building was constructed in 1885 by the Artistic Society (renamed the Art Union, founded in 1869), a private company headed by the painter Pedro Lira Rencoret (1845-1912) and Luis Dávila Larraín when it was acquired by the government from the University of Chile in 1887 . These initiatives that culminated with the relocation of the Museum of Fine Arts (Museo de Bellas Artes) were not immune to the sharp criticism of two men noted for their strength in artistic manners: Blanco and Lira ${ }^{6}$.

The museum remained in the Partenón de la Quinta Normal until September 21, 1910, with the Exhibition of Fine Arts and the triple inauguration of the building-museum-school in the Parque Forestal conceived by Emilie Jéquier (1866-1949) and designed by Dubois. Since then the museum has shared space with with the School of Fine Arts, formerly the Painting Academy founded in 1849 with the aim of promoting the arts in Chile by training artists and converting them into tasteful scholars.

This modern museum building, created with indifference to function -which must be noted on the international scene- included, in addition to the bulk of the collection which had been stored at the Partenón, the collection of Eusebio Lillo (1826-1910). According to Luis Cousiño, this comprises 124 pictures and 142 books on artistic matters. Also included are acquisitions from Maturana and Juan Francisco González among others from the Exposition of the Centry and other donations. A panoramic view will require a registration and detailed inventory, 1922 marking the beginning of the institutional publications with a first edition which was updated in

\footnotetext{
${ }^{4}$ Ossa (1984): 14.

${ }^{5}$ Zamorano, Madrid \& Cortés, Alpha 37 (2013): 149-162.

${ }^{6}$ De la Maza (2014): 91-129.
} 
1930, 1977, 1984 and 2009. Exceptions exist as with books such as that of RichonBrunet (1910), dedicated to the "International Exhibition" and generating other temporary exhibitions over the years. Other examples include catalogs published in 2000, such as "Chile. 100 años de Artes Visuales" and "Centenario. Exposición Internacional. Del pasado al presente. Migraciones” (2010).

\section{THE IMAGE OF THE MUSEM: ITS PUBLICATIONS}

Conceived as a hard cover, practical pocket book, Museo de Bellas Artes. Catálogo general de las obras de pintura, escultura, etc. it has since its publication become a work of obligatory consultation and study for anyone interested in the collections of the museum. Luis Cousiño Talavera, member of the Council of Fine Arts at the time and later director of the museum from 1922-1927, describes this work beginning in 1904 and even earlier, though much of this early documentation has little to no value (3-5).

In an exercise in ordering, the author identifies the parts that make up their particular catalogue:

- Author/Room/Number of the paintings (7-16).

- Plan of the museum in two illustrations.

- The Lillo Gallery $(17-158)^{7}$.

- The relationship of paintings stored, as in that period part of the museum's galleries were occupied by the Museum of Military History (159-173).

- The relationship of paintings located outside of the musuem (174-178):

- Temporarily stored at the School of Fine Arts (174-176).

- Held by the Ministry of Public Instruction (176-177).

- Held by the municipality of Santiago (177-178).

\footnotetext{
${ }^{7}$ In addition to Lillo, benefactor to the museum are Francisco Echaurren Huidobro, María Luisa Mac Clure de Edwards, Marcos Segundo Maturana, Alfredo Concha Vicuña, Ignacio Víctor Eyzaguirre, Alfredo Helsby, Pedro Lira, Víctor Echaurren Valero, Carlos García Huidobro, Francisco J. Mandiola, María Luisa Lynch de Gormaz... Subsequently reffered to, in some cases, by Vidor 8 years later.
} 
- The relationship of sculptures and two small showcases with objects for documentation (180-219).

- Sculptures and other objects of art (220-222).

- Sculptures and relics stored in the School of Fine Arts (223).

Unfortunately, the edition contains duplications in the text, repeating between pages 33 and 48, though it itself gives meaning to the collection as well as contextualizes it when necessary with biographies of its alleged perpetrators. It regrettably has no bibliography, but it does have capital value for the current state of the art collection at the museum. Predating the contributions of Álvarez Urquieta (between 1933 and 1934, mainly), there is undeniable merit in its substantial readings and artistic contextualizations.

El Museo de Bellas Artes, 1880-1930 is the work of Tomás Lago Pinto and Pablo Vidor Doctor, two of the most active figures in the Chilean cultural landscape during the first half of the 20th century. The first was a personality close to that of Neruda and of great relevance due to his studies of Chilean artesenal crafts and traditions as well as the first director of MAPA. As an academic of the University of Chile, Lago's forays into the field of art produced several books devoted to Ortiz de Zárate (1956) and Rugendas (1960) ${ }^{8}$. Vidor was a painter of Hungarian descent and Central European training. He served as director of the National Museum of Fine Arts between 1930 and 1933.

It is a book with two distinct parts, one written by Lago under the title "Precursores de la pintura chilena" (5-35) adorned with black and white illustrations: "El arte extranjero" (37-62) and "El arte nacional" (63-90); the other written by Vidor, "El Museo de Bellas Artes" (91-97), in turn divided into two parts. Vidor details the ups and downs of the museum and its associated cultural organizations, linking key figures, and finally summarizing the collection analysis from the end of the 19th century of which he had an undoubted interest due to his knowledge of European painting. The work culminates with "Obras obsequiadas al museo" (98-107) which, despite providing new data on the work of Cousiño, is rather puzzling as its numbering system is inconsistent.

In our view, it is a useful but somewhat unsuccessful project very much in line with what will later follow, not paying real attention to cataloging and though providing well-intentioned diatribes, largely ignoring the true foundations of the museum. It gives the impression that, unlike that of Cousiño, it is a half-job without even a bibliography, however a useful complement to the catalogue of 1922.

${ }^{8}$ Witker (2003): 148-158; Gazmuri (2009): 117 and 165. 
Almost half a century after the previous edition, under the successive direction of Alberto Mackenna (1933-1939), Ortiz de Zárate (1939-1946), Luis Vargas (1946-1970) and Antúnez (1970-1973), there seemed to be the least intention of continuing the work begun by Cousiño as well as distributing funding. During the same period between 1973 and 1977 the sculptress Lily Garafulic ${ }^{9}$ published a modest book of collaboration, Pintura chilena. Museo Nacional de Bellas Artes, headed by Isabel Cruz and Hernán Rodríguez. The book, being presented by the Director (5) and the "Reseña histórica del Museo Nacional de Bellas Artes" (7), explores the world of Chilean painting:

- Colonial painting in Chile (11-16).

- The dawn of national painting. The mulato Gil and European precursors (17-14).

- The first generations of Chilean artists and the Academy of Painting (25-33).

- Painters that became independent of the Academy in search of personal expression (34-37).

- Four great masters over the centuries and their influences (38-55).

- The Generation of 1913 (57-62).

- The Montparnasse Group, followers and related movements (63-73).

- Naive painting (74-77).

- Other modern movements in Chilean painting (78-82).

- Contemporary Chilean painting. The latest trends (83-85).

Considering all previous contributions in the field, especially those from Romera, the work was a true cornerstone in its analysis and interpretation of Chilean painting since first coming to light in 1951, with successive reissues. Upon further examination, there are parallels to Álvarez Urquieta and Romera, namely the lack of critical analysis or a bibliography. Though still useful, it does not overly support the cataloging process as the only known publication of the museum in 47 years.

The book Museo Nacional de Bellas Artes was driven by the direction of the Centre, headed by Nena Ossa Puelma (1978-1990), and written in collaboration with a large cast of specialists. It was of great substance and more carefully edited than those before it, recalling the origin of the museum, including new data on funding sources and consisting of more photography that text.

Its framework is divided into:

- A forward by the director of DIBAM (8-9).

\footnotetext{
${ }^{9}$ Cruz de Amenábar (2003).
} 
- An introduction from the director (13-24), in which some interesting details on the evolution of the museum are recorded, as well as an expanded list of leaders.

- "Colección chilena. Período colonial" (25-29).

- “1810-1984" (29-65).

- "Colección de pintura europea" (66-123), made up of "Pintura española" (66-74), "El Siglo de Oro en Holanda" (75-80), "Colección Wittgenstein y otras pinturas europeas" (81-87), a collection of Italian drawings from the 16th and 17th centuries (88-91), "Grabados alemanes del siglo XVI y XVII" (92-93), "Colección de escultura” (94-110), "La fotografía" (111$116)$ and "Obras donadas" (117-123).

- "Personal, actividades y espacios del museo" (125-143).

It was another missed opportunity to provide a cultural space for relevant information, thoughtful research and not merely a photographic catalogue. Even as amended in its last pages, it was a lost chance to reveal the details of the contributions of a place as important as it is symbolic for the Chilean artistic culture.

At the commemoration of Chile's 200th anniversary of independence and amongst the many events in both the capital and across the country, the museum contributed two separate but complementary publications. Both were created a quarter century after the previous work was published. Here we will address the most significant of the two, as the second is more of an editorial product of a temporary exhibition.

The work Centenario. Colección Museo Nacional de Bellas Artes. 1910-2010 was published in a luxury edition with couché paper. In the introduction Milan Ivelic, director of the institution between 1993 and 2011, distinguishes four stages in the museum's history according to the progressive increase of its collection. The first stage consists of 140 works. The second, of Jéquier, coincides with the Centennial Exposition where the museum acquired many donations from the likes of Maturana, Lillo, Juan Francisco González and others. The third stage is marked by the acquisition of the collection of Álvarez Urquieta, the donation of Wittgenstein, Santiago Ossa Amstrong or the legacy of Ismael Valdés. Finally, the fourth stage begins with the Medici project in 1995 and the addition of contemporary works thanks to the Corporation of Friends of the Museum, with purchases made since 2005 by the DIBAM (20-21).

According to Ivelic (20-21), "the publication proposes to order the artistic material that has been selected transversely, without necessarily holding to a linear chronology but rather rebuilding a museographic script." In other words, it enhances new readings different from previous ones, divergent from the discourse 
understood as linear or classic. Therefore, some of the various collaborators that accompany the director as co-authors or collaborators are those who trace the broad lines of the book:

- "El imaginario religioso", from M. Ivelic (22-29).

- "La narración histórica”, from M. Ivelic (30-41).

- "Retrato(s) de una colección”, from Ramón Castillo (42-103).

- "La mirada en reposo. Objeto cotidiano", from Angélica Pérez Germain (104-161).

- "Convergencia y divergencia”, from M. Ivelic (162-195).

- "Entorno al paisaje”, from Patricio M. Zárate (196-253).

- "El cuerpo del arte, entre el pudor y el desacato", from P. M. Zárate (254-311).

- "English version" (312-331).

We would say, from a certain perspective, that actors change and scripts vary to suit the times. The typeface improves substantially, but the positive yet disparate interpretations continue. The website of the institution is operational and includes a substantial part of what was previously overlooked by the first two publications, which were analyzed with a focus on other objectives. These texts perhaps should have emphasized the full significance of the museum in its influence on the culture and artistic tastes, as well as the artists themselves in Chile over the last 130 years.

\section{CONCLUSIONS}

Taking stock of the publication generated by the National Museum of Fine Arts in Chile over the course of the 134 years of its existence has been the goal of this work. It aims to be an exercise in constructive reflection that cannot be understood without addressing the context and cultural background which have influenced these works greatly. Likewise, it is necessary to consider other research dealing with the beginning of the History of Art in Chile since the mid 19th century.

Perhaps the main contribution comes in rethinking the artistic evolution, with its ups and downs, disputes and contradictions, along with an analysis of its correlation with a society that invited it to discover its identity. In the museums such as the one examined here are these achievements as well as the shortcomings, the promoters, managers and potential customers alongside the successes and failures ${ }^{10}$.

From this point of view, the museum and its collections (including its works that have been dispersed amongst other museums, a matter that should be

\footnotetext{
${ }^{10}$ Berríos et al. (2009); Berríos, Cancino \& Santibánez (2012).
} 
investigated) function as a record of those that have served the academy faithfully. These are those who have driven the research on the pioneers of History and Art with an almost dogmatic faith, compiling the narrow and dispersed heritage and going to primary sources when investigating. The bibliographical gaps in the universities also make up basic references which should be collected and made available for consultation at the National Library. In this sense, the effort made by the National Library in the last years in the 'Chilean memory' part of the web site is far from satisfactory, although it should be a useful platform for researchers to use.

In conclusion, Chile was not, as commonly thought, a cloistered and isolated country with its peculiar geography. Since early on it had the presence of people attracted to novelty and the foreign, willing to travel and learn about the outside world, bringing scientists, thinkers and artists from afar and, thereby, contributing to the cultural advancement of the country. Many of them were cultured, educated and bright, while others decided to prolong their stays in Europe, generating a fruitful debate in which ideas of all kinds were confronted passionately ${ }^{11}$. However, this unparalleled cultural rebirth has been blurred with the passing of the years, in some ways, to become a repetition of topics that have also affected the dynamism of discussion that should represent the National Museum of Fine Arts throughout its history. If not, how can it be understood that Chile does not have a modern museum of contemporary art independent from the university, as any advanced country? What is the point of using the back of the museum as the school of fine arts when the museum needed the space? These are contradictions hanging by a thread at the dawn of the 21st century that speak of the past inertia encysted in the present, but that also contradict the view of such illustrious ancestors, in many cases innovative in a great part of the continent.

\section{REFERENCES}

Berríos, Pablo et al. Del taller a las aulas. La institución moderna del arte en Chile (1797-1910). Santiago, Chile: Estudios de Arte, 2009.

Berríos, Pablo, Cancino, Eva \& Santibánez, Kaliuska. La construcción de lo contemporáneo. La institución moderna del arte en Chile (1910-1947). Santiago, Chile: Estudios de Arte, 2012.

Cousiño Talavera, Luis. Museo de Bellas Artes. Catálogo general de las obras de pintura, escultura, etc. Santiago, Chile: Sociedad Imprenta y Litografía Universo, 1922.

\footnotetext{
${ }^{11}$ Idem.
} 
Cruz de Amenábar, Isabel. Lily Garafulic. Forma y Signo en la Escultura Chilena Contemporánea. Santiago, Chile: Ediciones Universidad Católica de Chile, 2003.

Cruz, Isabel \& Rodríguez, Hernán. Pintura chilena. Museo Nacional de Bellas Artes. Santiago, Chile: Editorial Universitaria - Esso Chile - S.A. Petrolera, 1977.

De la Maza, Josefina. De obras maestras y mamarrachos. Notas para una historia del arte del siglo diecinueve chileno. Santiago, Chile: Ediciones Metales Pesados, 2014.

Gazmuri R., Cristián. La historiografía chilena (1842-1970). Tomo II (1920-1970). Santiago, Chile: Centro de Investigaciones Diego Barros Arana - Taurus Historia, 2009.

Herrera Styles, Patricia. "Pedro Lira y José Miguel Blanco: sus "luchas artísticas" y la articulación de un sistema del arte en Chile". En Raquel Abella et al. (Eds.), El sistema de las artes. VII Jornadas de Historia del Arte. Valparaíso, Chile: Museo Histórico Nacional, (2014): 61-70.

Ivelic, Milan (coord.). Centenario. Colección Museo Nacional de Bellas Artes. 19102010. Santiago, Chile: Museo Nacional de Bellas Artes, 2009.

Lago Pinto, Tomás \& Vidor Doctor, Pablo. El Museo de Bellas Artes, 1880-1930. Santiago, Chile: Universidad de Chile - Departamento de Extensión Cultural y Artística, 1930.

Ossa Puelma, Nena. Museo Nacional de Bellas Artes. Santiago, Chile: DIBAM, Colección Chile y su cultura. Serie Museos Nacionales, 1984.

Witker, Alejandro. Tomás Lago. Memorial Cultural de Nuble. Universidad de BioBio Municipalidad Chillán Viejo, 2003.

Zamorano Pérez, Pedro, Madrid Letelier, Alberto \& Cortés López, Claudio. “José Miguel Blanco: Escritor de Bellas Artes”, Alpha 37 (2013): 149-162. 